\title{
An Empirical Investigation of Competitive Exam Based Selection and Placement of Managerial Public Officials in Vietnam: Is It a Cure or a Curse?
}

\author{
Thai Thanh Ha ${ }^{1}$, Ton Duc Sau ${ }^{2}$ \\ ${ }^{1}$ National Academy of Public Administration (NAPA), Hanoi, Vietnam \\ ${ }^{2}$ Vietnam Posts and Telecommunications (VNPT), Hanoi, Vietnam \\ Email: thaiha63@yahoo.com, tonducsau@gmail.com
}

How to cite this paper: Ha, T.T. and Sau, T.D. (2018) An Empirical Investigation of Competitive Exam Based Selection and Placement of Managerial Public Officials in Vietnam: Is It a Cure or a Curse? Modern Economy, 9, 1179-1189.

https://doi.org/10.4236/me.2018.97077

Received: May 14, 2018

Accepted: July 16, 2018

Published: July 19, 2018

Copyright $\odot 2018$ by authors and Scientific Research Publishing Inc. This work is licensed under the Creative Commons Attribution International License (CC BY 4.0).

http://creativecommons.org/licenses/by/4.0/

\begin{abstract}
Competitive exams, selection, and placement of high-ranking public officials used to be resorted only by Vietnam's feudal dynasties. After half a century of abandonment, this practice seems to have made its spectacular comeback in the recent decade. In a quest for high caliber public personnel, the Vietnamese government believes that competitiveness-base exams would help select, recruit and place right public servants into the right job. This research was conducted to figure out to what extent the selected high-ranking post holders were different from the public service employers. Based on face-to-face interviews with candidates and the heads of public services employers who were going to place the selected ones onto the managerial posts, data were gathered for Structural Equation Modeling (SEM) analysis with the use of structured 5 point-Likert scale questionnaire in the field surveys. Findings showed that there existed a difference in the perceptions towards the fairness of the competitive exams among these two types of interviewees. By comparing SEM coefficients, several recommendations were drawn for policy makers and managers to modernize this type of recruitment, selection and placement of managerial public servants on the intended job positions.
\end{abstract}

\section{Keywords}

Competitive Exams, Selection, Placement, Public Services, Vietnam

\section{Introduction}

It is widely accepted that human resource plays an important role for things are 
getting done through its employees [1]. Nowadays, that important role is increasingly required by public employers in order to achieve high levels of performance aimed to address the many gaps that existed in different spheres of government service delivery and provision [2]. The public human resource serves as the link to bridge these gaps. Some scholars have considered the management-level personnel to be the hub around which the entire organization revolves [3] [4]. In trying to achieve the above mentioned function, a careful and well-planned recruitment, selection and satisfactory placement of managerial public servants is absolutely critical in order to ensure that only the right caliber of staff is employed for the public organization in need. A competitive exam is one of the popular forms that have been adopted both in developed and developing countries [5] [6]. However, it may differ from country to country depending on the geographical, political and socio-cultural background [7] [8].

In Vietnam competitive exams, also long time known as "Huong" and "Dinh" ones, were periodically held by feudal dynasties with the aim to pick up the talented functionaries to maintain the best governance of the kingdom. They were supposed to assist the king in orderly reigning his kingdom's well-wishers [9]. Ever abandoned since the 1945 independence declaration, this trend seemed to come back when the Vietnamese government has recently adopted the merit-based policy on selecting the public managerial officials in an effort to place the right people on the right public job tenures [9] [10] [11]. It has been firmly stated in the Vietnamese government policy that competitive exams should be the solid way of selecting qualified public officers and putting these highly capable people on the right managerial public service placements. In doing so, it would assist the heads of public employers and government jurisdictions in discovering the future leaders while avoiding the selection of public servants on the basis of judgments, personal sentiments or cronyism [4] [8] [10] [11].

Several cities and provinces of Central Vietnam have been the pioneer in adopting this method of recruiting, selecting and placing the public service officials in an attempt to make the public administration more efficient and capable of meeting the need for high-quality services required by Vietnamese citizen [12] [13]. All of this has been geared towards long-term visionary leaders in order to turn this dynamic city into "miniature Singapore" in the Central region of Vietnam [14]. However, this is easier said than done due to the lack of proper legal guidance documents. Furthermore, the complexity of competitive exams for this type of selection, recruitment and placement of the senior managerial posts has created another bottleneck on practical implementation [13] [15]. This research is therefore needed to set more light on the issue given the gap in the view point between academicians and practitioners. The policy implications should, thereafter, be drawn from the research findings and put into the practical use in order to modernize the process of recruitment, selection and placement of managerial public service officials generally in Vietnam [13] [14] [15] [16]. 


\section{Survey and Results}

\subsection{Survey Sample}

We adopted the quantitative technique for this research using collected data from the two types of key informants who, one way or the other, were directly involved in the process. They were the competitive exam participants and the heads of public employers who gave managerial job placements to the successful exam winners. To collect the information for analysis, a version of structured questionnaire using five-point Likert scale was developed and followed up in the face-to-face interviews. According to Hair et al. [17], a sample size must be sufficient when this type of quantitative research is to be carried out. A number of completed questionnaires amounted to 88 . The proportion was equally distributed for exam participants ( $50 \%$ of the sample size). The heads of employers who, making up the rest of $50 \%$ total interviewees, would give the job placement to the exam winners at the end of the process. Given a total of 15 statements laid out in the questionnaire, such a sample size had met the five-to-one rule-of-thumb requirements of the multivariate data analysis in this quantitative research [17] [18]. The demographic characteristics of the sample are presented in Table 1.

With regards to the gender proportion of the sample male respondents account for $57 \%$ as compared to female informants who took a share of $43 \%$ on the

Table 1. Demographic characteristics of the sample.

\begin{tabular}{|c|c|c|c|c|}
\hline \multirow{2}{*}{ Gender } & \multicolumn{2}{|c|}{ Exam participants } & \multicolumn{2}{|c|}{ Public Employers } \\
\hline & Number & $\%$ & Number & $\%$ \\
\hline Male & 25 & 57 & 11 & 25 \\
\hline Female & 19 & 43 & 33 & 75 \\
\hline Total & 44 & 100 & 44 & 100 \\
\hline Work experience & Number & $\%$ & Number & $\%$ \\
\hline $1-12$ years & 30 & 69 & 33 & 75 \\
\hline $13-22$ years & 7 & 17 & 8 & 18 \\
\hline Above 22 years & 6 & 14 & 3 & 7 \\
\hline Total & 44 & 100 & 44 & 100 \\
\hline \multirow{2}{*}{ Age } & \multicolumn{2}{|c|}{ Exam participants } & \multicolumn{2}{|c|}{ Public Employers } \\
\hline & Number & $\%$ & Number & $\%$ \\
\hline Below 30 & 10 & 23 & 6 & 14 \\
\hline $30-40$ years old & 24 & 55 & 24 & 55 \\
\hline 40 - 50 years old & 7 & 16 & 11 & 25 \\
\hline Above 50 & 3 & 6 & 3 & 6 \\
\hline Total & 44 & 100 & 44 & 100 \\
\hline
\end{tabular}

Source: Data from survey 2017. 
basis of the competitive exam participants. In the meantime, the gender distribution of the respondents was $25 \%$ for male respondents and $75 \%$ for female informants among the public employers which was allegedly supposed to place these exam winners on the managerial public job positions. In terms of work experience, the participants who had a work experience in 1 - 2 year bracket accounted for $69 \%$ as opposed to those with 13 - 22 years of work experience who participated in the competitive exam amounted to $17 \%$. The remaining exam participants who had more than 22 years of work experience took a meager share of $6 \%$. As it came to public employers which would place the exam winners on specific managerial positions, the proportion of those with different work experience were as follows: those with 1 - 2 years of work experience accounted for $75 \%$; those with 13 - 22 year seniority occupied $18 \%$ and the rest of public employers with more than 22 years of experience took a share of $7 \%$.

Concerning the age of the exam participants, those who were under the age of 40 amounted to $78 \%$ of the total interviewees. The rest of exam participants interviewed with the age above 40 took $22 \%$. In contrast, the proportion of interviewees who were the heads of public organizations utilizing the exam winners on a later stage, were $69 \%$ for the category of below $40 \%$ and $31 \%$ for the category of above 40 . Overall, the sample structure with the regards to gender, work experience and the age as described above were suitable and met with the multivariate data analysis techniques used in this quantitative study [17] [18].

\subsection{Results}

Because of a large number of item statements in the questionnaire we adopted the factor analysis to identify and confirm the hidden constructs. Several researchers have gone further in suggesting that factor analysis would assist in identifying the structure of relationships among item statements [17] [19]. These would be, in turn, used for explaining the hidden constructs. It can also help researchers create an entirely new set of variables from these items, much smaller in number, to partially or complete replace the original set of variables for inclusion in subsequent analysis. We ran normality test and came to conclusions that all items were proven to meet the Kolmorogov-Smirnov test for normality indicating that the necessary assumption for factor analysis was met [17] [18]. Furthermore, the KMO index for items reached the values of 0.85 which exceed the acceptable threshold. The criteria for a statistical significance of factor loadings were set that loadings greater than \pm 0.4 would be considered to meet the minimal level. A loading of \pm 0.5 or greater was considered to be practically significant [17] [20]. The results of the factor analysis are shown in Table 2. All the variables reach significant loadings. Variables with higher factor loadings were considered as being more important and having greater influence on the name or label selected to represent a factor [17] [19].

Factor 1 is named as Exam Guidelines and Contents. It measures the extent to which the competitive exam participants master the contents and guidelines 
Table 2. Factor analysis of the contructs.

\begin{tabular}{|c|c|c|}
\hline Factors & Item statements & $\begin{array}{l}\text { Factor } \\
\text { loadings }\end{array}$ \\
\hline \multirow{7}{*}{$\begin{array}{l}\text { Factor } 1 \text { : } \\
\text { Cronbach } \\
\text { Alpha }=0.8 ; \\
\text { Variance } \\
\text { explained = } 41.5 \% \text {; } \\
\text { Eigenvalue }=6.23 \\
\text { Labeled as } \\
\text { Exam guidelines } \\
\text { and contents }\end{array}$} & $\begin{array}{l}\text { 1. Exam participants have given the best answers to the } \\
\text { questions raised by the examiners. }\end{array}$ & 0.801 \\
\hline & $\begin{array}{l}\text { 2. Exam contents set a context in which exam participants } \\
\text { would be able to express their managerial leadership style. }\end{array}$ & 0.776 \\
\hline & $\begin{array}{l}\text { 3. Ability of candidates has been proven with regards to public } \\
\text { presentation. }\end{array}$ & 0.727 \\
\hline & $\begin{array}{l}\text { 4. Knock-out questions are consistent to identify the } \\
\text { competitive exam winners and to pick out the right champions. }\end{array}$ & 0.597 \\
\hline & $\begin{array}{l}\text { 5. Synthesizing the exam scores is logical for candidates to } \\
\text { interpret and appreciate. }\end{array}$ & 0.518 \\
\hline & $\begin{array}{l}\text { 6. The competitive exam is relevant and practically applicable for } \\
\text { recruitment, selection and placement of public managerial position. }\end{array}$ & 0.509 \\
\hline & $\begin{array}{l}\text { 7. Benchmarks and criteria are consistent for first-hand } \\
\text { identification of the exam candidates. }\end{array}$ & 0.503 \\
\hline \multirow{5}{*}{$\begin{array}{l}\text { Factor 2: } \\
\text { Cronbach } \\
\text { Alpha = 0.78; } \\
\text { Variance explained } \\
=11.6 \% ; \\
\text { Eigenvalue = } 1.356 \\
\text { Labeled as } \\
\text { Requirements of } \\
\text { "What-to-do" } \\
\text { Proposal }\end{array}$} & $\begin{array}{l}\text { 8. Exam contents are closely related to job description } \\
\text { for intended public managerial positions. }\end{array}$ & 0.746 \\
\hline & $\begin{array}{l}\text { 9. "what-to-do" proposal as worked out by the exam } \\
\text { candidates is feasible. }\end{array}$ & 0.696 \\
\hline & $\begin{array}{l}\text { 10. In most cases "what-to-do" proposal as worked } \\
\text { out by the candidates are able to project the future } \\
\text { developments of the organization. }\end{array}$ & 0.665 \\
\hline & $\begin{array}{l}\text { 11. Competitive exams are held on the basis of job description as } \\
\text { required by the managerial position in the public delivery offices. }\end{array}$ & 0.649 \\
\hline & $\begin{array}{l}\text { 12. Qualifications and capabilities of the competitive } \\
\text { exam participants are reflected in their proposal. }\end{array}$ & 0.635 \\
\hline $\begin{array}{l}\text { Factor 3: } \\
\text { Cronbach Alpha }= \\
0.63 ; \text { Variance }\end{array}$ & $\begin{array}{l}\text { 13. The logics and consistency of the "what-to-do" proposal } \\
\text { goes along with the status quo, objectives and goals to } \\
\text { be achieved by the public employers afterwards. }\end{array}$ & 0.749 \\
\hline $\begin{array}{l}\text { explained }=7.6 \% \\
\text { Eigenvalue }=1.046 \\
\text { Labeled as }\end{array}$ & $\begin{array}{l}\text { 14. The practicality and applicability of the competitive } \\
\text { exams are ensured on the part of functionality and } \\
\text { responsibility taken by public delivery services. }\end{array}$ & 0.544 \\
\hline $\begin{array}{l}\text { Exam Assessment } \\
\text { Benchmarks }\end{array}$ & $\begin{array}{l}\text { 15. The presentation of the "what-to-do" proposal } \\
\text { by each individual exam participants is professional and impressive. }\end{array}$ & 0.508 \\
\hline
\end{tabular}

as to what they are supposed to follow. The scores on these items were averaged to compute a value for this factor. The Cronbach Alpha reliability test for this factor was 0.8 which exceeds the acceptable threshold of 0.7 as suggested by [17] [18] [19] [20]. By the same token, factor 2 was labeled as Requirements of "What-to-do" Proposal. It measures the extent to which the exam participants meet the requirements of consistency and feasibility of what they are going to do as laid out in the proposal in case of being given the job position. The Cronbach Alpha reliability test for this factor was 0.78 with explained variance of $11.6 \%$ which is acceptable. The third factor was calculated in the same way and labeled as Exam Assessment Benchmarks. It reflects the degree to which the percep- 
tion is measured with regards the set of assessment criteria to be used in the competitive exams. The Cronbach Alpha reliability test for this third factor was 0.63 with explained variance of $7.6 \%$ which is marginally acceptable. All of these three factors would be used as independent variables. To assess the perceived fairness of the competitive exam, one item on 5-point Likert scale was used [17] [20].

This was introduced into the Structural Equation Modeling (SEM) as dependent variable. The SEM path analysis is shown in Figure 1. The structural equation modeling (SEM) technique was adopted and its results were presented separately for exam winners and the heads of public organizations adopting these peoples and giving them the job placement.

The results of Model 1 were run for the group of heads of public organizations who would use those selected participants. The overall fit measures indicate satisfactory level for model 1 as can be seen in Figure 1 . The Chi-square value $\left(\chi^{2}\right)$ reaches the value of 36.681 with degree of freedom at 15 while statistical p-value is at 0.001; RMSEA at 0.181 and the goodness-of-fit Index (GFI) at 0.990 which exceeds the threshold of 0.9 as suggested by different scholars using this SEM method [17] [20] [21]. Concerning the independent variables in the SEM analysis, such as Exam guidelines and contents; Requirements of "what-to-do" proposal; Exam Assessment Benchmarks, all of these three variables were positively correlated with the perceived fairness assessment of the competitive exam with the respective SEM $\beta$ coefficients of $0.08 ; 0.15$ and 0.12 . However, the demographic variables were put into the model. Namely, they were variables of age; gender; and work experience (measured in working years). These variables had the SEM $\beta$ coefficients of $0.09 ;-0.23$ and 0.1 at the statistical significance $\alpha=$ 0.05 , thus confirming the strong relation to the dependent variables in the SEM model [17].

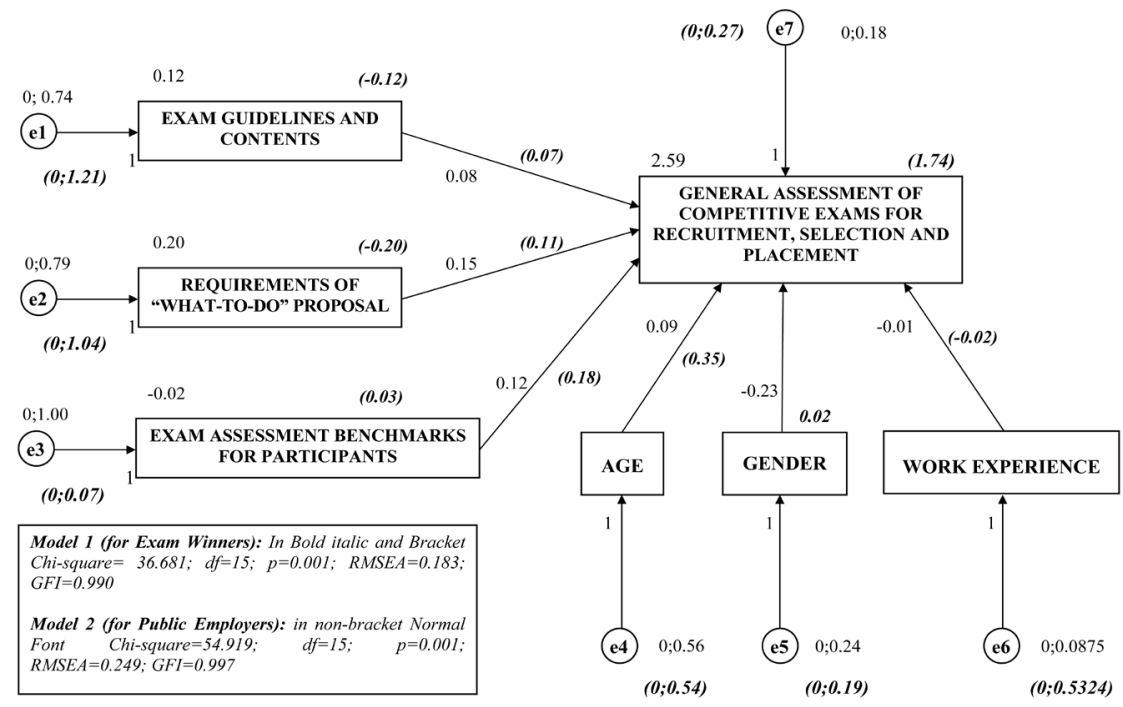

Figure 1. Structural Equation Modeling analysis for exam participants and public employers. Source: 2017 Survey data analysis using AMOS software. 
For the group of exam winners, the overall fit measures for the model were satisfactory with the $\mathrm{p}$-value $=0.00 ; \chi^{2}=54,919 ; \mathrm{df}=15$. The other fit measures such as RMSEA = 0.249; and Goodness-of-fit Index $(\mathrm{GFI})=0.997$ which all exceeded the threshold of 0.9 by Hair et al. (2007), indicating that the data fit the structural equation model very well and satisfactorily met the evaluation criteria. The SEM results for this group also indicate the independent variable known as Exam guidelines and contents possesses the SEM $\beta$ coefficient $=0.07$. Similarly, the independent variable named as Requirements of "what-to-do" proposal has the structural equation modeling $\beta=0.11$. At the same time, the variable known as factor 3 "Exam Assessment Benchmarks" maintains its SEM $\beta$ coefficient = 0.18 . All these three independent variables are positively correlated with the dependent variable with regard to the general perceived assessment of competitive exam for recruitment, selection and placement from the view point of the participants. In this SEM analysis, the gender served as dummy variable with male = 1 and female $=0$. It is indicated in Figure 1 that there is a different perception regarding the fairness of the competitive exam among male and female participants. Namely, male exam participants tend to have a higher level of perception on the fairness of the exam on recruitment, selection and placement of managerial public position as compared to that of female participants. This is because the SEM $\beta$ coefficient is at the value of 0.02 for gender variable in the model 2 as shown in Figure 1. In a similar way the age of the participants has also exerted a positive impact on the general assessment of perceived fairness of the competitive exams as the SEM $\beta$ coefficient is 0.35 for this variable in the model 2 . The variable of work experience moves in the opposite direction when its SEM $\beta$ coefficient reaches the SEM $\beta$ coefficient of -0.02 . The results of SEM analysis for this group of exam participants indicate a practical implication for competitive exams organizers. Firstly, it should be related to the potential participants to be put into the short list prior to the official start of the exam. This can be seen as a pre-requisite to identify the champions who stand above the crowd. Secondly, based on this the right people could be selected and afterward put into job placement of the managerial public position. Table 3 summarizes the path coefficients for these two models that were run for respective groups of key informants.

\section{Conclusions}

The comparison of Structural Equation Modeling path coefficients $\beta$ between the two groups of key informants using structural equation modeling analysis indicates some interesting implications for policy maker. As can be seen in Table 2, the heads of public employers which would put the exam winners on the desired managerial public job placement tended to have a higher degree of influence on the perceived assessment of exam fairness than the exam participants themselves. Namely, they are reflected in the aspects of Exam guidelines and contents (X4); Requirements of "what-to-do" proposal (X5) the exam candidates 
Table 3. Structural Equation Modeling Path diagram for competitive exam participants and public employers.

\begin{tabular}{|c|c|c|c|c|}
\hline \multirow[t]{2}{*}{ Structural Equation Modeling paths } & \multicolumn{2}{|c|}{$\begin{array}{l}\text { SEM model 1: } \\
\text { For competitive exam } \\
\text { participants }\end{array}$} & \multicolumn{2}{|c|}{$\begin{array}{c}\text { SEM model 2: } \\
\text { For public } \\
\text { organizations/employers }\end{array}$} \\
\hline & $\begin{array}{c}\text { Path coefficient } \\
\beta\end{array}$ & p-value & $\begin{array}{c}\text { Path coefficient } \\
\beta\end{array}$ & p-value \\
\hline \multicolumn{5}{|l|}{ Exam guidelines and contents (X4) $\rightarrow$} \\
\hline $\begin{array}{c}\text { General assessment of exam fairness } \\
\text { (Yi) }\end{array}$ & 0.07 & 0.031 & $0.08^{*}$ & 0.034 \\
\hline $\begin{array}{c}\text { Requirements of “what-to-do" proposal } \\
\text { (X5) } \rightarrow \text { General assessment of exam } \\
\text { fairness (Yi) }\end{array}$ & 0.11 & 0.012 & $0.15^{\star}$ & 0.060 \\
\hline \multicolumn{5}{|l|}{ Exam Assessment Benchmarks (X6) $\rightarrow$} \\
\hline $\begin{array}{c}\text { General assessment of exam fairness } \\
\text { (Yi) }\end{array}$ & $0.18^{*}$ & 0.03 & 0.12 & 0.029 \\
\hline $\begin{array}{c}\text { Age }(\mathrm{X} 3) \rightarrow \text { General assessment of exam } \\
\text { fairness (Yi) }\end{array}$ & $0.35^{*}$ & 0.02 & 0.09 & 0.03 \\
\hline Gender (coded as male $=1$ and female & & & & \\
\hline $\begin{array}{c}=0)(\mathrm{X} 1) \rightarrow \text { General assessment of exam } \\
\text { fairness (Yi) }\end{array}$ & $0.02^{\star}$ & 0.01 & -0.23 & 0.05 \\
\hline $\begin{array}{l}\text { Work experience }(\mathrm{X} 2) \rightarrow \text { General } \\
\text { assessment of exam fairness }(\mathrm{Yi})\end{array}$ & -0.02 & 0.03 & $-0.01^{*}$ & 0.025 \\
\hline
\end{tabular}

Source: 2017 Survey data analysis. Asterisk $\left(^{*}\right)$ indicates the overwhelming trend with regards to $\beta$ coefficients in path diagram.

were supposed to meet. The work experience (X2) of the heads of public employers seemed to show that the competitive exams were rather fair on the basis of their perceived assessment as opposed to the exam candidates who considered the exam as not fair as their expectations should be. The findings of this research also coincided with what has been synthesized by the National Assembly, Vietnamese Government and concerned ministries [4] [22] [23]. They are also partially confirmed in the study of several scholars and researchers [21] [24]-[30]. In the meantime, the participants who took the exam to get the managerial public position had a higher degree of influence on the general assessment of the exam fairness. These included such variables as Exam Assessment Benchmarks (X6); Age (X3); and Gender (X1) in the model 2. This very thing suggests that the selection of the examination committee members needs to be carefully taken into consideration. That is, apart from the professionally suitable set of benchmarks against which each individual candidate was to be evaluated, the diverse composition of examinees must be established with the aim to maintain the fairness and transparency of the exam. This recommendation requires the exam organizers to focus on this matter. This is also a critical aspect leading to the right selection of the right people who would swear in and take the managerial public post once they were selected, recruited and placed on the tenure. In a nutshell, fairness and transparency is sensitive matter for every exam for it serves as a basis for building up the trust and confidence in every exam candidate [31].

The refreshment of human resource and personnel development is the first priority for Vietnam. The Vietnamese government has issued a Master Plan for 
the public administration reform program, putting an utmost importance on the selection, recruitment and placement of managerial public positions, which has become one of the core components [22] [23] [31]. In a more concrete form, the Vietnamese Ministry of Home Affairs, also known as MOHA, has recently pushed forwards the public human resource and personnel strategy from now up to the year of 2020 [22] [23]. A stronger course of action would be taken by the MOHA in rolling out this Master Plan in practice [4] [16] [31]. And this type of competitive exam must be considered as a major approach to identifying, selecting, recruiting and placing the best public servants on desired managerial public tenures, not only at the city level, but also at the central government and the provincial department levels as well. Therefore, this research was expected to set some light on the policy implications to bring about the success for the Master Plan on Public Administration Reform program. Namely: Exam guidelines and contents should be consistent with the job description of the post. Requirements of "what-to-do" proposal should be laid out in more detail and with a practical feasibility. Exam Assessment Benchmarks are to be justified and quantified with concrete criteria on the sound basis of requirements that the incumbent exam winners would meet [9] [13] [16] [22] [23]. Besides, the intrinsic essence of the exam candidates are also the key factor that help the public employers to select the right candidates and place them righteously on the managerial public job tenures in later stage [28] [29]. It is also a decisive factor that leads to a better public service motivation of those who are selected, recruited and placed on the job in public employers. All of this is to be geared toward the citizen's satisfaction with regards to the public service quality [19] [24] [27].

\section{Acknowledgements}

The research is financed by National Academy of Public Administration (NAPA), an arm-length of the Ministry of Home Affairs (MOHA), Vietnam, grant number 453/QĐ-HVHC. Special thanks would go to Prof. Dr. Nguyen Dang Thanh, Ex-Deputy Minister of the MOHA who gave out encouraging supports for this research and realized the field trip to conduct the interviews to key informants in the cities of Vietnam.

\section{References}

[1] Khan, A. (2015) An Empirical Analysis of HR Policies on the Performance of Employees in Banking Industry: A Case Study of State Bank of India (SBI). International Journal of Multidisciplinary Research and Development, 2, 308-312.

[2] Piyawadee, R. and Farhad, H. (2014) HRM Reform in Decentralized Local Government: Empirical Perspectives on Recruitment and Selection in the Philippines and Thailand. International Journal of Public Administration, 35, 553-561.

[3] Agard, C. (2017) Recruitment Strategies, Matrices, and Techniques Used in Hiring Veterans. International Journal of Human Resource Studies, 7, 78-212. https://doi.org/10.5296/ijhrs.v7i2.10960

[4] ISOS (2018) Recruitment of Civil Servants in Vietnam. 
[5] ISOS (2013) Refreshment of Competitive Exams for Selection, Recruitment and Placement of Public Servants in the Ministry of Home Affairs, Vietnam.

[6] Akuamoah, W.S., Amedagbui, K., Buabasah, D.Y. and Letsa, A.K. (2016) The Impact of Effective Recruitment and Selection Practice on Organizational Performance: A Case Study at University of Ghana. Global Journal of Management and Business Research: Administration and Management, 16, Version 1.0 Year 2016.

[7] Akponuvire, M. (2005) The Ecology of Recruitment and Selection of Personnel in the Federal Civil Services of Nigeria. Journal of Human Resources Ecology, 17, 31-37. https://doi.org/10.1080/09709274.2005.11905754

[8] Maidoki, B.P. and Dahida, D.P. (2013) A Critical Examination of Recruitment Strategy in India and Nigeria. Public Policy and Administration Research, 3, 16-22.

[9] Thai, P.H. (2018) Selection and Placement of Functionaries in the Past Feudal Dynasties of Vietnam. Vietnamese Journal of Governmental Organizations, 1, 1-23.

[10] Danang Department of Home Affairs (2013) Decision 6621/QĐ-UBND Dated 2nd August 2013 on Rules and Regulations on Competitive Exam for Selection and Recruitment of Managerial Posts at Public Departments and Offices.

[11] National Assembly (2008) Laws on Cadre and Civil Servants. No 22/2008/QH12 Issued on 13 November 2008.

[12] Eswaranathan, E., Ayesha Samie, S. and Shagesheela, Mu. (2014). The Recent Challenges of Globalization and the Role of Employee Engagement-The Case of Vietnam. Journal of Human Resource Studies, 5, 69-85.

https://doi.org/10.5296/ijhrs.v5i1.6896

[13] Government of Vietnam Office (2015) Notice No 202-TB/TW on the Conclusions of Politburo Regarding to Organize Competitive Exams for Selection, Recruitment, and Placement of the Heads of Provincial Departments and Functionaries.

[14] Channel News Asia (2018) Singapore, Vietnam Sign Six Agreements to Boost Cooperation.

[15] Aloysius, T.A. and Mary, N.I. (2016) Implication of Recruitment Policies and Procedures for Employee Productivity in Enugu State Civil Service. African Journal of Basic \& Applied Sciences, 8, 80-86.

[16] Hao, N.T. (2013) Competitive Exams: Creating Sources of Public Human Resources for Development.

[17] Hair, et al. (2007) Multivariate Data Analysis. McGraw Hill Publishing House, New York.

[18] Arbuckle, J. (2015) IBM SPSS and AMOS 22 User Guide.

[19] Cardona, F. (2006) Recruitment in Civil Service Systems of EU Members and in Some Candidate States. Seminar on Civil Service Recruitment Procedures, Vilnius, 21-22 March 2006, 1-21.

[20] Swierczek, F.W. and Ha, T.T. (2003) Motivation, Entrepreneurship and Performance of SMEs in Vietnam. Journal of Enterprising Culture, 11, 47-68. https://doi.org/10.1142/S0218495803000044

[21] Berman, E., Bowman, J., West, J. and Van Wart, M. (2016) Human Resource Management in Public Service: Paradoxes, Processes, and Problems. 5th Edition, Sage Publications, Inc., London.

[22] MOHA (2017) Decision No 2631/QĐ-BNV on Pilot Regulations to Organize Competitive Exams for Selection, Recruitment, and Placement of the Heads of MOHA's Functionaries.

[23] Office of the Government (2011) The Master Plan for the 2011-2020 General Public 
Administration Reform Program.

[24] Bernard, O. and Bernadette, I.O. (2014) Staff Recruitment and Selection Process in the Nigerian Public Service: What Is to Be Done? International Journal of Human Resource Studies, 4, 280-293. https://doi.org/10.5296/ijhrs.v4i3.6367

[25] Djabatey, E.N. (2012) Recruitment and Selection Practices of Organizations, a Case Study of HFC Bank (GH) Ltd. MBA Thesis, Kwame Nkrumah University of Science and Technology.

[26] Emmanuel, J.A.A. (2014) Civil Service Recruitment: Problems Connected with Federal Character Policy in Nigeria. Journal of Public Administration and Governance, 4, 12-25. https://doi.org/10.5296/jpag.v4i2.5604

[27] Piyawadee, R. and Farhad, H. (2012) Decentralized Recruitment and Selection in Thailand: Friend or Foe to Local Public Administration? International Journal of Public Administration, 35, 553-561. https://doi.org/10.1080/01900692.2011.653513

[28] Mukoro, A. (2005) The Ecology of Recruitment and Selection of Personnel in the Federal Civil Services of Nigeria. Journal of Human Ecology, 17, 31-37. https://doi.org/10.1080/09709274.2005.11905754

[29] Yaro, I. (2014) Recruitment and Selection in the Nigerian Public Service: Nature, Challenges and Way Forward. British Journal of Economics, Management \& Trade, 4, 1005-1017. https://doi.org/10.9734/BJEMT/2014/7941

[30] Olatunji, E.S. and Ugoji, I.E. (2013) Impact of Personal Recruitment on Organizational Development: A Survey of Selected Nigerian Workplace. International Journal of Business Administration, 4, 79-103.

[31] MOHA (2017) Guidance No 2424/BNV-CCVC on the Implementation of Pilot Program to Select, Recruit and Place the Heads of Departments and Functionaries. 